\title{
An Experimental Investigation on The Mechanical Behaviour of Polypropylene Fibre Reinforced Concrete Using Ferrous Slag as A Partial Replacement of Fine Aggregate
}

\author{
G. R. Ravikanth"1, D. Mohammed Rafi², Dr. C. Ramachandrudu ${ }^{3}$
}

${ }^{1}$ M.Tech Scholar, St. Mark Educational Institution Society Group of Institutiions, Anantapur, Andhra Pradesh, India

${ }^{2}$ Assistant Professor, ${ }^{3}$ Professor, Civil Engineering Department, Chiranjeevi Reddy Institute of Engineering \& Technology, Anantapur, Andhra Pradesh, India

\begin{abstract}
Globally construction industry has enormous growth year by year. This leads to increase the need for construction materials. We are taking the materials from natural resources because of this natural resource depletion occurs at a faster rate. Also, this affects the environment. Cement production leads to higher amount of $\mathrm{CO} 2$ emission similarly depletion in river sand leads to ground water problems. So we have to find some alternate materials to conserve the earth for next generation. The faster industrial growth generates large amount of industrial wastes. Industrial waste material management is such a challenging area. Handling and disposal of industrial waste is a big issue for every country around the world. Ferrous slag is considered as an industrial waste which is obtained from iron smelting process. To minimize the environmental problems ferrous slag is used in concrete as a partial replacement of fine aggregate. Concrete is strong in compression and weak in tension. Using Polypropylene fibre we can increase the tensile strength of concrete. Mainly polypropylene fibre resists the micro plastic shrinkage cracks. Here polypropylene fibres added as micro reinforcement. But not much research has been carried out to study the combined behaviour of ferrous slag and Polypropylene fibre. The percentages of replacements of sand by granulated ferrous slag are $0 \%, 20 \%$, \& $50 \%$ and also the fibre dosage is maintained as constant $0.5 \%$ of cement. This research focused on the combined behaviour of ferrous slag and polypropylene fibre in study strength and transport properties.
\end{abstract}

Keywords : Ferrous Slag, Polypropylene, Compressive Strength, Tensile Strength

\section{INTRODUCTION}

The global use of concrete is second only to water. As the demand for concrete as a construction material increases, so also the demand for Fine aggregate increases. The concrete industry globally will consume $8-12$ billion tons annually of natural aggregate after the year 2010. Such large consumption of natural aggregates will cause destruction to the Environment. Several efforts are in progress to reduce the use of natural river sand as fine aggregate in concrete in order to address the ground water issues \& natural aggregate depletion. The beneficial use of by-products in concrete technology has been well known for many years and significant research has been published with regard to the use of materials such as coal fly ash, pulverized fuel ash, blast furnace slag and silica fume as partial replacements for Portland cement. Such materials are widely used in the construction of industrial and 
chemical plants because of their enhanced durability compared with Portland cement. The other main advantage of using such materials is to reduce the cost of construction. As for as fine aggregate is the concern so many researches are carried out for alternate material. Ferrous Slag is a by-product material produced from the process of manufacturing Iron. It is totally inert material and its physical properties are similar to natural sand. Ferrous Slag is a by-product in the manufacture of pig iron and the amounts of iron and slag obtained are of the same order. The slag is a mixture of lime, silica, and alumina, the same proportion. The composition of Ferrous Slag is determined by that of the ores, fluxing stone and impurities in the coke charged into blast furnace. Similarly M-Sand also used as fine aggregate. M-Sand is processed from the crushed rock of gravel.

\subsection{Ferrous Slag}

Ferrous slag is an industrial by-product obtained during the matte smelting and refining of pig iron. It has been estimated that approximately 300 to $540 \mathrm{~kg}$ per tonne of pig or crude iron are produced. The amount of slag produced by many of the countries in the world in large amounts and many of them export the slag in large amounts such as China, USA, Japan and Nepal about 602120, 30000, 23868 and 13138 tons respectively.

Although ferrous slag is widely used in the cement industry and in the manufacturing of slag cement, the remainder is disposed of without any further reuse or reclamation. Ferrous slag possesses mechanical and chemical characteristics that qualify the material to be used in concrete as a partial replacement for Portland cement or as a substitute for aggregates. For example, ferrous slag has a number of favorable mechanical properties for aggregate use such as excellent soundness characteristics, good abrasion resistance and good stability. Also, ferrous slag exhibits pozzolanic properties since it contains high $\mathrm{CaO}$ content and other oxides such as $\mathrm{Al} 2 \mathrm{O} 3, \mathrm{SiO} 2$, and $\mathrm{Fe} 2 \mathrm{O} 3$. Use of ferrous slag in the concrete industry as a replacement for cement and/or fine aggregates can has the benefits of reducing the costs of disposal and helps protecting the environment. Ferrous slag used in this work was brought from JSW Steel Ltd, Bellary, Karnataka, India. JSW Steel Ltd is producing ferrous slag during the manufacture of Steel. It is a by-product obtained during the matter smelting and refining of iron. To produce every ton of steel, approximately 2.2- 3.0 tons ferrous slag is generated as a by-product material. Utilization of ferrous slag in applications such as Portland cement substitution and/or as aggregates has threefold advantages of eliminating the costs of dumping, reducing the cost of concrete, and minimizing air pollution problems.

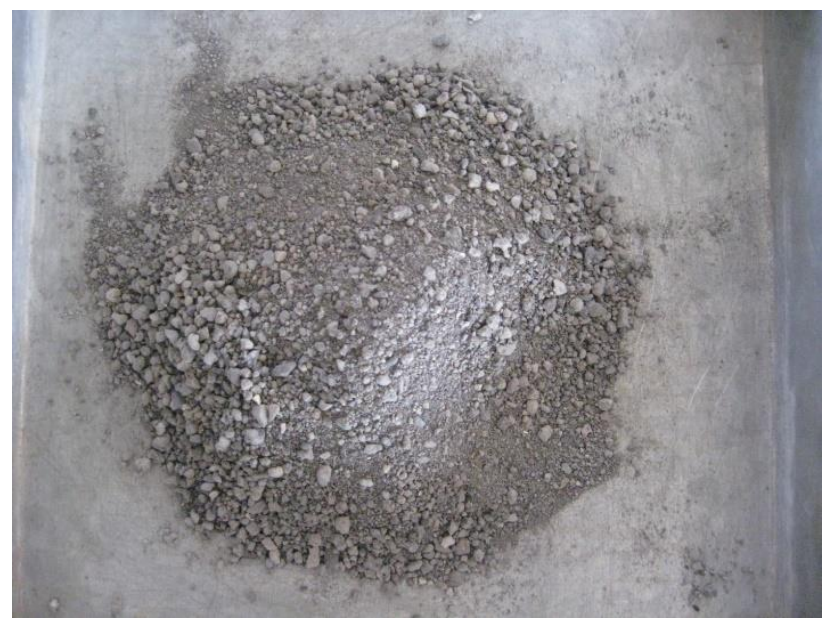

Figure 1.1 Sample of Ferrous slag

\section{MANUFACTURING PROCESS}

In nature iron ore is found in impure state, often oxidized and mixed with other metals. During smelting, when the ore is exposed to high temperature, these impurities are separated from the molten metal and can be removed. Slag is the collection of compounds that are removed. In many smelting processes, oxides are introduced to control the slag chemistry, assisting in the removal of impurities and protecting the furnace refractory 
lining from excessive wear. In this case, the slag is termed synthetic.

Ferrous and non-ferrous smelting processes produce different slags. The smelting of ferrous and nonferrous for instance, is designed to remove the iron and silica that often occurs with those ores, and separates them as iron-silicate-based slags. As the slag is channelled out of the furnace, water is poured over it. This rapid cooling, often from a temperature of around $2,600{ }^{\circ} \mathrm{F}\left(1,430{ }^{\circ} \mathrm{C}\right)$, is the start of the granulating process. This process causes several chemical reactions to take place within the material, and gives the slag its cementitious properties.

The water carries the slag in its slurry format to a large agitation tank, from where it is pumped along a piping system into a number of gravel based filter beds. The filter beds then retain the slag granules, while the water filters away and is returned to the system. When the filtering process is complete, the remaining slag granules, which now give the appearance of coarse beach sand, can be scooped out of the filter bed and transferred to the grinding facility where they are ground into particles of desired size.

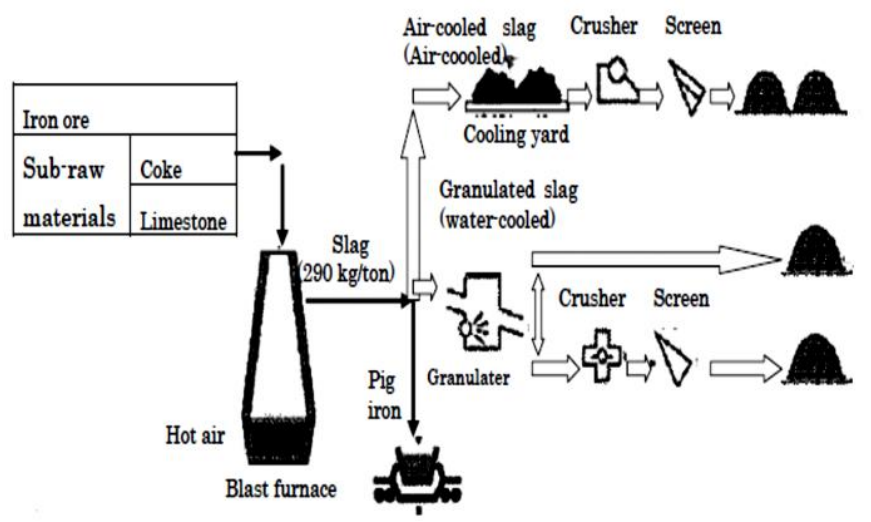

Figure 2.1 Ferrous Slag Production Process

\section{Uses of Ferrous Slag}

* They can be used as aggregates in the concrete mixing.

* Used as raw feed in the kiln to produce clinker.

* Slag cements are produced in large amounts.

* They can be used as base and surface materials.

\subsection{Polypropylene Fiber}

Concrete is by nature a brittle material that performs well in compression, but is considerably less effective when in tension. Latest developments in concrete technology now include reinforcement in the form of fibers, notably polymeric fibers, as well as steel or glass fibers 1-5. Fiber-reinforcement is predominantly used for crack control and not structural strengthening. Although the concept of reinforcing brittle materials with fibers is quite old, the recent interest in reinforcing cement-based materials with randomly distributed fibers is quite old; the recent interest in reinforcing cement based materials with randomly distributed fibers is based on research starting in the 1960's. Since then, there have been substantial research and development activities throughout the world. It has been established that the addition of randomly distributed polypropylene fibers to brittle cement based materials can increase their fracture toughness, ductility and impact resistance. Since fibers can be premixed in a conventional manner, the concept of polypropylene fiber concrete has added an extra dimension to concrete construction. 


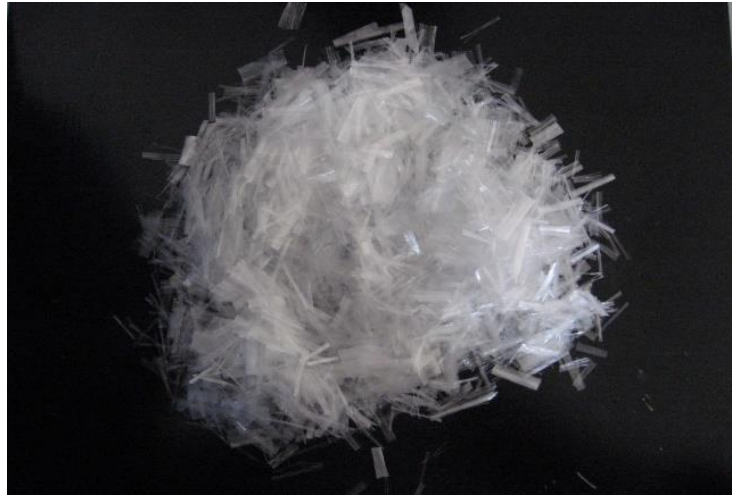

Figure 2.2 Sample of Polypropylene Fiber

It is a thermo plastic fiber and its structure is based on $\mathrm{C}_{n} \mathrm{H}_{2 n}$ monomer. This is manufactured from propylene gas in presence of titanium chloride. Poly propylene has an intermediate level of crystallinity between low density polyethylene (LDPE) and high density polyethylene (HDPE). The first polypropylene resin was produced by Giulio Natta in Spain, although commercial production began in 1957.

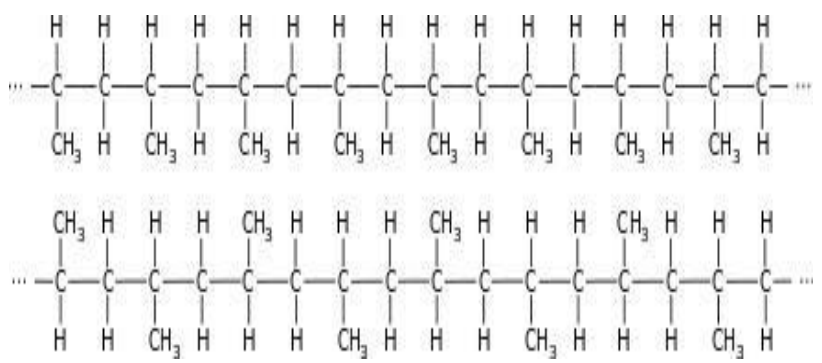

Figure 2.3 Polypropylene Monomer

Polypropylene chips can be converted to fiber/filament by traditional melt spinning, though the operating parameters need to be adjusted depending on the final products. Spun bonded and melt blown processes are also very important fiber producing techniques for nonwovens. As an example, the staple fiber production is shown in following figure. Identifiers are shown with the figure.

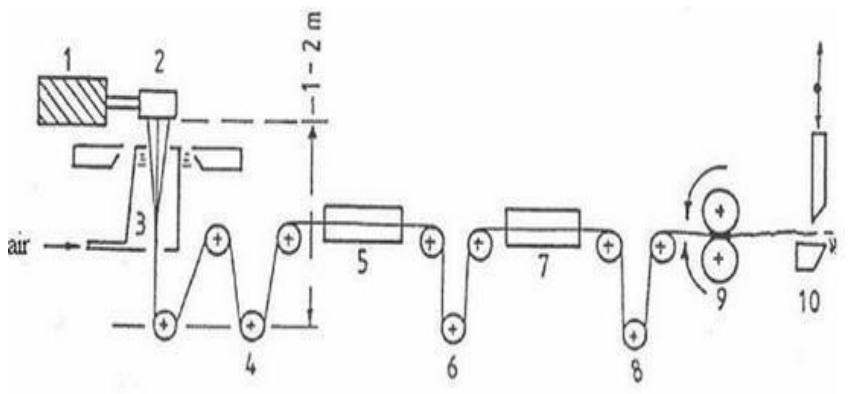

1-extruder, 2-Spinning pack, 3-Ouench duct.4.6.8-Drawing.Tensioning,

5-Hot streching,7-stabilizing,9-Crimper 10-cutter

Figure 2.4 Manufacturing process of PPF

\section{MATERIALS AND PROPERETIES}

This chapter explains about the materials and its properties. It also includes mix proportions and mixing.

Cement: Cement is the most important material in the concrete and it act as the binding material. Ordinary Portland cement of 53 grade manufactured by dalmia cements is used in this investigation. Various properties of the cement has been tested according to IS 12269-1987 and IS 4031 -1988.

Aggregate: The basic objective in proportioning any concrete is to incorporate the maximum amount of aggregate and minimum amount of water into the mix, and thereby reducing the cementitious material quantity, and to reduce the consequent volume change of the concrete.

Coarse aggregate: Selection of the maximum size of aggregate mainly depends on the project application, workability, segregation, strength and availability. In this research aggregates that are available in the crusher nearby was used. The maximum size of aggregate was varying between $26-12.5 \mathrm{~mm}$.

Fine aggregate: The amount of fine aggregate usage is very important in concrete. This will help in filling the voids present between coarse aggregate and they mix with cementitious materials and form a paste to coat aggregate particles and that affect the compactability of the mix. The aggregates used in this research are without impurities like clay, shell 
and organic matters. It is passing through $4.75 \mathrm{~mm}$ sieve.

\section{Ferrous Slag}

Ferrous slag is an industrial by-product obtained during the matte smelting and refining of pig iron. It has been estimated that approximately 300 to $540 \mathrm{~kg}$ per tonne of pig or crude iron are produced. Although ferrous slag is used in many of the industries large amounts of the slag is still left out as dumping waste. So the ferrous slag properties are checked over and they resembles nearer to the aggregates and glassy properties they are used as the substitute materials in the cement and concrete as the raw materials. In this project we are using the slag that had been produced in the JSW Steel Ltd.

\section{Polyproplene}

Polypropylene (PP), also known as polypropene, is a thermoplastic polymer used in a wide variety of applications including packaging and labeling, textiles (e.g., ropes, thermal underwear and carpets), stationery, plastic parts and reusable containers of various types, laboratory equipment, loudspeakers, automotive components, and polymer banknotes. An addition polymer made from the monomer propylene, it is rugged and unusually resistant to many chemical solvents, bases and acids

Table 3.1: Physical Properties of Ferrous Slag

\begin{tabular}{|l|l|l|}
\hline S.no & Particulars & Results \\
\hline 1 & Type & $\begin{array}{l}\text { Industrial } \\
\text { Waste }\end{array}$ \\
\hline 2 & Specific Gravity & 3.4 \\
\hline 3 & Water absorption & $4 \%$ \\
\hline 4 & Fineness modulus & 3.06 \\
\hline 5 & Grading & Zone II \\
\hline 6 & Density & \\
\hline
\end{tabular}

Table 3.2: Chemical Properties of Ferrous Slag

\begin{tabular}{|l|l|l|}
\hline S.no & Particulars & Percentage \\
\hline 1 & Cao & 36.35 \\
\hline 2 & $\mathrm{Mgo}$ & 9.59 \\
\hline 3 & $\mathrm{Al}_{2} \mathrm{O}_{3}$ & 16.21 \\
\hline 4 & $\mathrm{SO}_{3}$ & 1.78 \\
\hline 5 & $\mathrm{SiO}_{2}$ & 35.20 \\
\hline 6 & $\mathrm{Fe}_{2} \mathrm{O}_{3}$ & 0.56 \\
\hline
\end{tabular}

\section{EXPERIMENTAL INVESTIGATION}

\subsection{Compressive Strength Test}

Compression test is done confirming to IS: 516-1953. All the concrete specimens that are tested in a 2000KN capacity Compressive-testing machine. Concrete cubes of size $150 \mathrm{~mm} \times 150 \mathrm{~mm} \times 150 \mathrm{~mm}$ and cylinders of size $100 \mathrm{~mm}$ dia \& $200 \mathrm{~mm}$ height were tested for crushing strength, crushing strength of concrete was determined by applying load at the rate of $1400 \mathrm{~N} / \mathrm{cm}^{2} / \mathrm{min}$ till the specimens fail. The maximum load applied to the specimens was recorded and divided the failure load with crosssectional area of the specimens for compressive strength has been calculated.

\section{Compressive Strength of concrete=Load/Area}

Compressive strength test was conducted on cubes of $150 \mathrm{mmX} 150 \mathrm{mmX} 150 \mathrm{~mm}$ cubes for the various mixes M1, M2, M3 and M4 of concrete. The details about the loading and strength of the specimens are given in the table 4.1 and 4.2 .

\subsection{Split Tensile Strength Test}

The cylinders were subjected to split tensile tension by replacing them horizontally on the ailoure in the 2000KN CTM. The load is applied uniformly at a constant rate until failure by splitting along the vertical diameter takes place load at which the 
specimens failed is recorded and the splitting tensile stress is obtained using the formula based on IS: 5816-1970.

\section{$F_{t}=2 P / \pi D L$}

Where $\mathrm{P}=$ Compressive load on the cylinder $\mathrm{L}=$ Length of the cylinder $\mathrm{D}=$ Diameter of the cylinder

Split tensile strength has done for the mixes M1, M2, M3, and M4 of concrete for 1 day, 7 days and 28 days. The test has conducted on the cylinder of $100 \mathrm{mmX} 200 \mathrm{~mm}$. The details about the loading and strength of the specimens are given in the following tables.

Table 4.1 : Compressive strength details

\begin{tabular}{|c|c|c|c|c|c|c|c|}
\hline \multicolumn{8}{|c|}{ Compressive Strength Details of Specimens in $\mathrm{KN} / \mathrm{mm}^{2}$} \\
\hline \multirow{2}{*}{$\begin{array}{l}\mathrm{Mi} \\
\mathrm{x}\end{array}$} & \multirow{2}{*}{$\begin{array}{l}\text { cube } \\
\mathrm{s}\end{array}$} & \multicolumn{2}{|c|}{3 days } & \multicolumn{2}{|l|}{7 days } & \multicolumn{2}{|c|}{28 days } \\
\hline & & Load & avg & Load & avg & load & avg \\
\hline \multirow{3}{*}{ M1 } & 1 & $\begin{array}{l}11.55 \\
6\end{array}$ & \multirow{3}{*}{11.57} & $\begin{array}{l}23.555 \\
6\end{array}$ & \multirow{3}{*}{$\begin{array}{l}23.62 \\
9\end{array}$} & $\begin{array}{l}27.55 \\
6\end{array}$ & \multirow{3}{*}{$\begin{array}{l}28.66 \\
7\end{array}$} \\
\hline & 2 & $\begin{array}{l}11.33 \\
3\end{array}$ & & $\begin{array}{l}24.222 \\
2\end{array}$ & & $\begin{array}{l}28.88 \\
9\end{array}$ & \\
\hline & 3 & $\begin{array}{l}11.82 \\
2\end{array}$ & & $\begin{array}{l}23.111 \\
1\end{array}$ & & $\begin{array}{l}29.55 \\
6\end{array}$ & \\
\hline \multirow{3}{*}{ M2 } & 1 & $\begin{array}{l}12.75 \\
6\end{array}$ & \multirow{3}{*}{$\begin{array}{l}12.23 \\
7\end{array}$} & $\begin{array}{l}25.555 \\
6\end{array}$ & \multirow{3}{*}{$\begin{array}{l}24.66 \\
7\end{array}$} & $\begin{array}{l}30.22 \\
2\end{array}$ & \multirow{3}{*}{$\begin{array}{l}29.92 \\
6\end{array}$} \\
\hline & 2 & $\begin{array}{l}12.08 \\
9\end{array}$ & & $\begin{array}{l}24.222 \\
2\end{array}$ & & $\begin{array}{l}28.88 \\
9\end{array}$ & \\
\hline & 3 & $\begin{array}{l}12.08 \\
9\end{array}$ & & $\begin{array}{l}24.222 \\
2\end{array}$ & & $\begin{array}{l}30.66 \\
7\end{array}$ & \\
\hline \multirow{3}{*}{ M3 } & 1 & $\begin{array}{l}11.86 \\
7\end{array}$ & \multirow{3}{*}{12.34} & $\begin{array}{l}23.777 \\
8\end{array}$ & \multirow{3}{*}{24.74} & $\begin{array}{l}26.22 \\
2\end{array}$ & \multirow{3}{*}{$\begin{array}{l}28.59 \\
2\end{array}$} \\
\hline & 2 & $\begin{array}{l}11.73 \\
3\end{array}$ & & $\begin{array}{l}23.555 \\
6\end{array}$ & & $\begin{array}{l}30.66 \\
7\end{array}$ & \\
\hline & 3 & $\begin{array}{l}13.42 \\
2\end{array}$ & & $\begin{array}{l}26.888 \\
9\end{array}$ & & $\begin{array}{l}28.88 \\
9\end{array}$ & \\
\hline \multirow{3}{*}{ M4 } & 1 & $\begin{array}{l}11.86 \\
7\end{array}$ & \multirow{3}{*}{$\begin{array}{l}10.60 \\
7\end{array}$} & $\begin{array}{l}23.777 \\
8\end{array}$ & \multirow{3}{*}{$\begin{array}{l}21.25 \\
9\end{array}$} & $\begin{array}{l}24.44 \\
4\end{array}$ & \multirow{3}{*}{$\begin{array}{l}22.07 \\
4\end{array}$} \\
\hline & 2 & $\begin{array}{l}8.844 \\
4\end{array}$ & & $\begin{array}{l}17.777 \\
8\end{array}$ & & $\begin{array}{l}21.33 \\
3\end{array}$ & \\
\hline & 3 & $\begin{array}{l}11.11 \\
1\end{array}$ & & $\begin{array}{l}22.222 \\
2\end{array}$ & & $\begin{array}{l}20.44 \\
4\end{array}$ & \\
\hline
\end{tabular}

Table 4.2 : Split Tensile Strength details

\begin{tabular}{|c|c|c|c|c|c|c|c|}
\hline \multicolumn{8}{|c|}{ Split Tensile Strength Details of Specimens in $\mathrm{KN} / \mathrm{mm}^{2}$} \\
\hline \multirow{2}{*}{$\begin{array}{l}\mathrm{Mi} \\
\mathrm{x}\end{array}$} & \multirow{2}{*}{$\begin{array}{l}\text { cube } \\
\mathrm{s}\end{array}$} & \multicolumn{2}{|c|}{3 days } & \multicolumn{2}{|l|}{7 days } & \multicolumn{2}{|c|}{28 days } \\
\hline & & Load & avg & Load & avg & load & avg \\
\hline \multirow{3}{*}{ M1 } & 1 & $\begin{array}{l}1.432 \\
4\end{array}$ & \multirow{3}{*}{$\begin{array}{l}1.347 \\
4\end{array}$} & $\begin{array}{l}2.0690 \\
1\end{array}$ & \multirow{3}{*}{$\begin{array}{l}2.042 \\
3\end{array}$} & $\begin{array}{l}2.228 \\
2\end{array}$ & \multirow{3}{*}{$\begin{array}{l}2.201 \\
4\end{array}$} \\
\hline & 2 & $\begin{array}{l}1.336 \\
9\end{array}$ & & $\begin{array}{l}2.1485 \\
9\end{array}$ & & $\begin{array}{l}2.148 \\
6\end{array}$ & \\
\hline & 3 & $\begin{array}{l}1.273 \\
2\end{array}$ & & $\begin{array}{l}1.9098 \\
5\end{array}$ & & $\begin{array}{l}2.228 \\
2\end{array}$ & \\
\hline \multirow{3}{*}{ M2 } & 1 & $\begin{array}{l}1.750 \\
7\end{array}$ & \multirow{3}{*}{$\begin{array}{l}1.787 \\
6\end{array}$} & $\begin{array}{l}2.0690 \\
1\end{array}$ & \multirow{3}{*}{$\begin{array}{l}2.148 \\
6\end{array}$} & $\begin{array}{l}2.307 \\
7\end{array}$ & \multirow{3}{*}{$\begin{array}{l}2.307 \\
7\end{array}$} \\
\hline & 2 & $\begin{array}{l}1.782 \\
5\end{array}$ & & $\begin{array}{l}2.2281 \\
6\end{array}$ & & $\begin{array}{l}2.228 \\
2\end{array}$ & \\
\hline & 3 & $\begin{array}{l}1.830 \\
3\end{array}$ & & $\begin{array}{l}2.1485 \\
9\end{array}$ & & $\begin{array}{l}2.387 \\
3\end{array}$ & \\
\hline \multirow{3}{*}{ M3 } & 1 & $\begin{array}{l}1.432 \\
4\end{array}$ & \multirow{3}{*}{$\begin{array}{l}1.442 \\
9\end{array}$} & $\begin{array}{l}2.4191 \\
5\end{array}$ & \multirow{3}{*}{$\begin{array}{l}2.397 \\
8\end{array}$} & $\begin{array}{l}2.546 \\
5\end{array}$ & \multirow{3}{*}{$\begin{array}{l}2.572 \\
9\end{array}$} \\
\hline & 2 & $\begin{array}{l}1.464 \\
2\end{array}$ & & $\begin{array}{l}2.3873 \\
2\end{array}$ & & $\begin{array}{l}2.546 \\
5\end{array}$ & \\
\hline & 3 & $\begin{array}{l}1.432 \\
4\end{array}$ & & $\begin{array}{l}2.3873 \\
2\end{array}$ & & $\begin{array}{l}2.626 \\
1\end{array}$ & \\
\hline \multirow{3}{*}{ M4 } & 1 & $\begin{array}{l}2.228 \\
2\end{array}$ & \multirow{3}{*}{$\begin{array}{l}1.962 \\
7\end{array}$} & $\begin{array}{l}2.3873 \\
2\end{array}$ & \multirow{3}{*}{$\begin{array}{l}2.413 \\
7\end{array}$} & $\begin{array}{l}2.864 \\
8\end{array}$ & \multirow{3}{*}{$\begin{array}{l}2.970 \\
8\end{array}$} \\
\hline & 2 & 2.069 & & 2.4669 & & $\begin{array}{l}3.023 \\
9\end{array}$ & \\
\hline & 3 & $\begin{array}{l}1.591 \\
5\end{array}$ & & $\begin{array}{l}2.3873 \\
2\end{array}$ & & $\begin{array}{l}3.023 \\
9\end{array}$ & \\
\hline
\end{tabular}

\section{REFERENCES}

[1]. IS 10262:1982 'Hand Book of Concrete Mix Design', Bureau of Indian Standards, New Delhi

[2]. IS 383:2000, 'Code of Practice for Plain and Reinforced Concrete', (4th Revision), Bureau of Indian Standards, New Delhi.

[3]. IS 383:1970, Specification for coarse and fine aggregates from natural sources for concrete

[4]. IS 5816:1999 Splitting Tensile Strength of Concrete Test.

[5]. M.S. SHETTY (2000).,Concrete Technology, S.CHAND and Company Ltd.

[6]. M.L. GAMBHIR (1998) "Concrete Technology", Tata McGraw-Hill 
[7]. ACI Committee 2111, (1994) mechanical properties and time dependent deformation of polypropylene fiber concrete. ACI Manual of Concrete Practice.

[8]. ACI Committee 544, (1982) properties of concretes containing polypropylene, steel and reengineered plastic shred fiber.

Cite this article as :

G. R. Ravikanth, D. Mohammed Rafi, Dr. C. Ramachandrudu, "An Experimental Investigation on The Mechanical Behaviour of Polypropylene Fibre Reinforced Concrete Using Ferrous Slag as A Partial Replacement of Fine Aggregate", International Journal of Scientific Research in Science and Technology (IJSRST), Online ISSN : 2395-602X, Print ISSN : 2395-6011, Volume 6 Issue 1, pp. 252-258, January-February 2019. Available at doi : https://doi.org/10.32628/IJSRST196136 Journal URL : http://ijsrst.com/IJSRST196136 